\title{
Comparison of 3 Doses of Aloe vera and Burn Drugs in Market on Burnt Rat Models
}

\author{
Çağlar Macit ${ }^{*}$, M. Eşref Tatııınar², Emre Şefik Çağlar ${ }^{3}$, Neda Taner ${ }^{4}$, Senanur Turgut ${ }^{5}$, \\ Elif Görkem Sarıkaya ${ }^{5}$

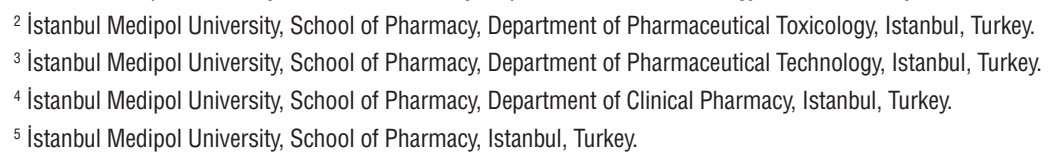

\section{ABSTRACT}

Burn injuries are an incident that can have serious traumatic consequences. Degree of tissue damage depends on height of heat and duration of contact. It can be classified as 4 different burn degrees. Herbal treatments can be applied for alleviating the symptoms alongside with pharmacological treatments in clinic. Aloe vera are used for burn cases for so many years because of its antiinflammatory, antiviral, antifungal, antibacterial, antidiabetic and rapid burn wound healing effects. Our aim in this study is to compare different doses of Aloe vera gel with burn medications in market. 48 female Sprague-Dawley rats divided into 8 groups (negative control, positive control, Silverdin $\AA$, Bepanthol $\AA$, Sudocrem $\AA$, Aloe vera $30 \mathrm{mg}$, Aloe vera $60 \mathrm{mg}$, Aloe vera $90 \mathrm{mg}$ ). For burn modelling, back of the rats were exposed to $90^{\circ} \mathrm{C}$ hot water which in the $1,5 \mathrm{~cm}$ diameter falcon tube for 10 seconds (burnt area: 7,069 cm2). After the modelling, serum physiologic was applied to each rat. Their treatments were always given at the same time. Experimental study was carried out with 14 numbered approval of Istanbul Medipol University Animal Experiments Local Ethical Committee. Obtained data were evaluated with SPSS v21 programme. After 15 days treatment, $30 \mathrm{mg}$ of Aloe vera was more effective than Silverdin $\AA$ cream (Aloe vera decreased burnt area: 3,064 cm2, Silverdin $\AA$ decreased burnt area: 3,731 cm2). The most effective drug among these medications is Sudocrem $₫$ with decreased burnt area $2,302 \mathrm{~cm} 2$. Consequently, it can be seen that Sudocrem $\AA$ is the most effective drug when comparing with these medications for burn treatment, and $30 \mathrm{mg}$ dose of Aloe vera is better than Silverdin $\AA$ cream.

Keywords: Burn, aloe vera, Sudocrem $®$, Silverdin $®$

\section{INTRODUCTION}

As a natural result of invention of fire, humanity encounters burn wounds since then. These wounds bring along injuries and deaths with them. Especially because of burn wounds, severe defects and also death may occur, according to its grade.

*Corresponding author: Çağlar Macit, e-mail: cmacit@medipol.edu.tr (Received 01 March 2018, accepted 30 March 2018) 
Extent of tissue damage depends on heat temperature and duration of contact. The severity of an injury is determined by measuring depth and width of the wound. Wound depth is identified mostly by clinical observation. Even the most experienced physicians can be misled when doing wound depth determination. There are several methods for wound depth determining but these are not generally accepted by experts. ${ }^{1}$

Evaluation of burnt patient is done in two steps which are primary (first) and secondary (reexamination) evaluation.,3 In the primary evaluation, life-threatening conditions are determined with rapid and systematic approaches. Urgent intervention and first aid operations are done in this step. Airway, breathing, circulation controls and immobilization of neck vertebrates are done, respectively. More detailed evaluation is taken part in second step and then patient transport is carried out and wound and maintenance treatment come after shock treatment. ${ }^{4}$

In the treatment of burn wound, wound depth determination is done after the clearance of wound. Wounds that has partial thickness are healed spontaneously. In first degree burns, 4-7 days are needed to recovery and 2-4 weeks for second degree burns. In this period, burn wound is protected from the outside by closing the wound. ${ }^{5}$

In recent years, nonpharmacological approaches with some plants for wound healing became popular and one of them is Aloe vera. Aloe has been used as a folk medicine because it has several important therapeutic properties. ${ }^{6}$ It can fight against fungal, viral and bacterial disease. Additionally, it has analgesic and antidiabetic effects. Beside these, Aloe forces and supports immune system of people. ${ }^{7,8}$

In this study, we aimed to compare burn medicines in market with 3 different doses of Aloe vera preparations in rats that were formed as model of burn.

\section{METHODOLOGY}

\section{Devices}

We used various laboratory equipment such as fridge/deep frost, homogenizer, hot water bath, $50 \mathrm{~mL}$ falcon tube, surgical scissors, pliers, lancet, bistouries, surgical gloves, 5-10 mL syringes and ruler.

\section{Chemical Substances and Drugs}

For anesthesia; isoflurane (Forane-Abbott) and ketamine/xylazine (90/10 mg/ $\mathrm{kg}$ ) were used. For treatment; we used silver sulfadiazine (Silverdin $\AA$, Deva), dexpanthenol (Bephantol $\AA$, Bayer), zinc oxide (Sudocrem $\AA$, MA Holder \& Manufacturer) and Carbopol 934, triethanolamine, isopropyl alcohol and glycerin for preparation of Aloe vera gels. Silverdin, Bepanthol and Sudocrem were obtained from community pharmacies. Medicinal Aloe vera plant was purchased from Albanian Gardens greenhouse and gel was obtained by cutting of its 
leaves. Finally, formulation was prepared at Istanbul Medipol University, School of Pharmacy, Department of Pharmaceutical Technology.

\section{Formulation of Aloe vera Gel}

Gel was prepared before addition of Aloe vera. Gel formulation is;

Carbopol 934 $1 \mathrm{~g}$

Triethanolamine $3,5 \mathrm{~g}$

Isopropyl alcohol $20 \mathrm{~g}$

Glycerin $7 \mathrm{~g}$

Distilled water q.s. $100 \mathrm{~g}$

Preparation: Carbopol 934 and glycerin were mixed with each other, this mixture was homogenized by adding 50 grams of water. Homogenized isopropyl alcohol and water mixture was added into first mixture. Then, triethanolamine was dissolved in water and added into mixture dropwise. This mixture was stirred until the completion of gelation. Then, the mixture completed with water to the desired weight.

\section{Animal Supply and Care Conditions}

In this study, 48 female Sprague-Dawley rats which ranging in weight from 150 to 200 grams were used. Experimental study was carried out with 14 numbered approval of Istanbul Medipol University Animal Experiments Local Ethical Committee. Rats were obtained from Istanbul Medipol University. During the quarantine, rats were kept at a stable temperature $\left(23 \pm 1{ }^{\circ} \mathrm{C}\right)$ for 12 hours. Also, they were kept for 12 hours in light and for 12 hours in dark. They were fed with standard rat food and allowed to reach water (tap water/ad libitum) (Figure 1).

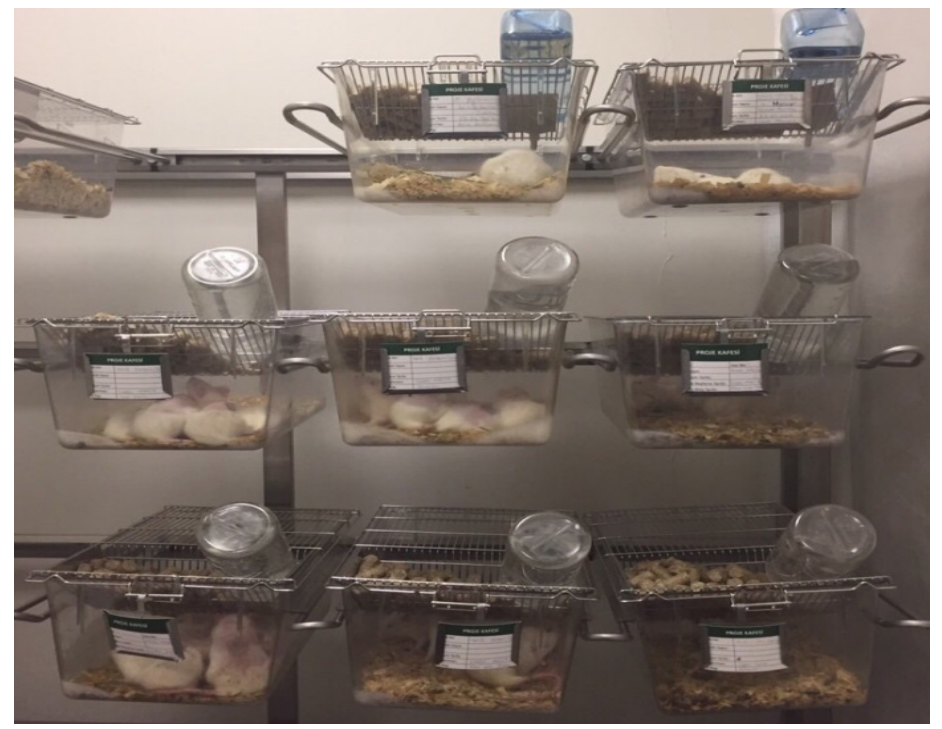

Figure 1. Sprague-Dawley rats and experimental groups. 


\section{Burn Damage and Experimental Modelling}

Current legal practices about experimental animal care were considered before, during and after the study. Rats were randomly divided into 8 groups $(n=6)$. Experimental groups were named as; Group 1-negative control (completely healthy), group 2-positive control (burnt rats, no treatment), group 3-Silver$\operatorname{din} \AA$, group 4-Bepanthol $\AA$, group 5-Sudocrem $\AA$, group 6-Aloe vera $30 \mathrm{mg}$, group 7-Aloe vera $60 \mathrm{mg}$, group 8-Aloe vera $90 \mathrm{mg}$ (Table 1 ).

Table 1. Experimental groups and applied drugs

\begin{tabular}{ll}
\hline Group Name & Applied Drugs \\
\hline Group 1 & None \\
Group 2 & None \\
Group 3 & Silverdin Cream \\
Group 4 & Bepanthol Cream \\
Group 5 & Sudocrem \\
Group 6 & Aloe vera $30 \mathrm{mg}$ gel \\
Group 7 & Aloe vera $60 \mathrm{mg}$ gel \\
Group 8 & Aloe vera $90 \mathrm{mg}$ gel \\
\hline
\end{tabular}

Rats' backs were shaved under anesthesia. Their backs were sterilized with alcoholed cotton. Falcon tubes that has $3 \mathrm{~cm}$ diameter were filled with $90^{\circ} \mathrm{C}$ hot water. Rats were exposed to these water in falcon tubes for 10 seconds. After the exposure, second degree burns were occurred. After this process, rats were injected $5 \mathrm{ml}$ saline to their napes subcutaneously and 1 drop of saline was given to each rats' eyes. Positive and negative control groups were not treated. Other groups of rats were treated with their selected drugs.

Treatment was continued with selected drugs once a day for 15 days. Positive and negative control groups were sacrificed after 2 days from forming burn model. After 15 days, the other groups were sacrificed. 
Table 2. Working fiction

\begin{tabular}{|c|c|c|c|c|c|c|c|}
\hline \multicolumn{8}{|c|}{ Groups } \\
\hline Group 1 & Group 2 & Group 3 & Group 4 & Group 5 & Group 6 & Group 7 & Group 8 \\
\hline & \multicolumn{7}{|c|}{ After exposing rats to $90^{\circ} \mathrm{C}$ hot water for 10 seconds } \\
\hline $\begin{array}{l}\text { Sham } \\
\text { group } \\
\text { (only } \\
\text { shaving) }\end{array}$ & $\begin{array}{l}\text { Untreated } \\
\text { control } \\
\text { group } \\
\text { that were } \\
\text { formed } \\
\text { burnt rat } \\
\text { model }\end{array}$ & $\begin{array}{l}\text { Silverdin } ® \\
\text { cream was } \\
\text { applied to } \\
\text { burnt area }\end{array}$ & $\begin{array}{l}\text { Bepanthol }{ }^{\circledR} \\
\text { cream was } \\
\text { applied to } \\
\text { burnt area }\end{array}$ & $\begin{array}{l}\text { Sudocrem® } \\
\text { was applied } \\
\text { to burnt area }\end{array}$ & $\begin{array}{c}\text { Aloe } \\
\text { vera } 30 \\
\text { mg was } \\
\text { applied } \\
\text { to burnt } \\
\text { area }\end{array}$ & $\begin{array}{c}\text { Aloe } \\
\text { vera } 60 \\
\text { mg was } \\
\text { applied } \\
\text { to burnt } \\
\text { area }\end{array}$ & $\begin{array}{c}\text { Aloe } \\
\text { vera } 90 \\
\text { mg was } \\
\text { applied } \\
\text { to burnt } \\
\text { area }\end{array}$ \\
\hline \multicolumn{2}{|c|}{$\begin{array}{c}\text { Sacrificed after } 2 \\
\text { days }\end{array}$} & \multicolumn{6}{|c|}{ Sacrificed after 15 days } \\
\hline
\end{tabular}

\section{Statistical analysis}

Obtained data were analyzed with the use of SPSS v.21 statistic program. The data were analyzed with 1-way ANOVA followed by the Duncan test. Data were shown as mean \pm SD. Camparison of two data was done by the test and if $p<0,05$, it was considered as statistically significant.

\section{RESULTS}

Table 3. Burn areas of experimental groups on stated days.

\begin{tabular}{|c|c|c|c|c|c|c|c|}
\hline & Silverdin $®$ & Bepanthol $®$ & Sudocrem $\AA$ & $\begin{array}{c}\text { Aloe } \\
\text { vera } \\
30 \mathrm{mg}\end{array}$ & $\begin{array}{c}\text { Aloe } \\
\text { vera } \\
60 \mathrm{mg}\end{array}$ & $\begin{array}{c}\text { Aloe } \\
\text { vera } \\
90 \mathrm{mg}\end{array}$ & $\mathrm{SD}( \pm)$ \\
\hline Day 1 & 7,07 & 7,07 & 7,07 & 7,06 & 7,07 & 7,07 & 0 \\
\hline Day 7 & 5,30 & 5,72 & 5,48 & 5,24 & 5,83 & 5,76 & 0,24 \\
\hline Day 10 & 4,75 & 4,90 & 3,89 & 4,39 & 4,91 & 4,55 & 0,38 \\
\hline Day 15 & 3,73 & 3,72 & 2,30 & 3,06 & 3,52 & 3,43 & 0,54 \\
\hline
\end{tabular}

*The data were analyzed with 1-way ANOVA followed by the Duncan test $(p<0,05)$. 


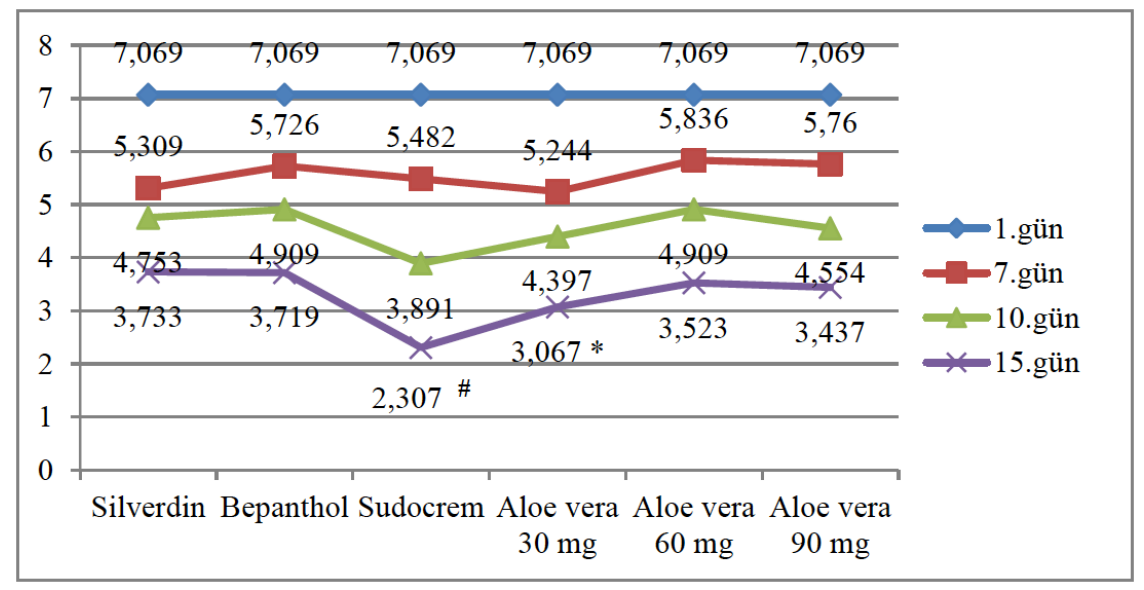

Figure 2. Graphical display of burn areas of experimental groups on stated days.

*: compared with other groups except Sudocream when $15^{\text {th }}$ days of treatment; \#: compared with all groups when $15^{\text {th }}$ days of treatment.

At the end of the study, our results showed that area of burn was smaller in Sudocream group compared with those of other groups $(\mathrm{p}<0,05)$. It can be shown in Table 3 and Figure 2. 


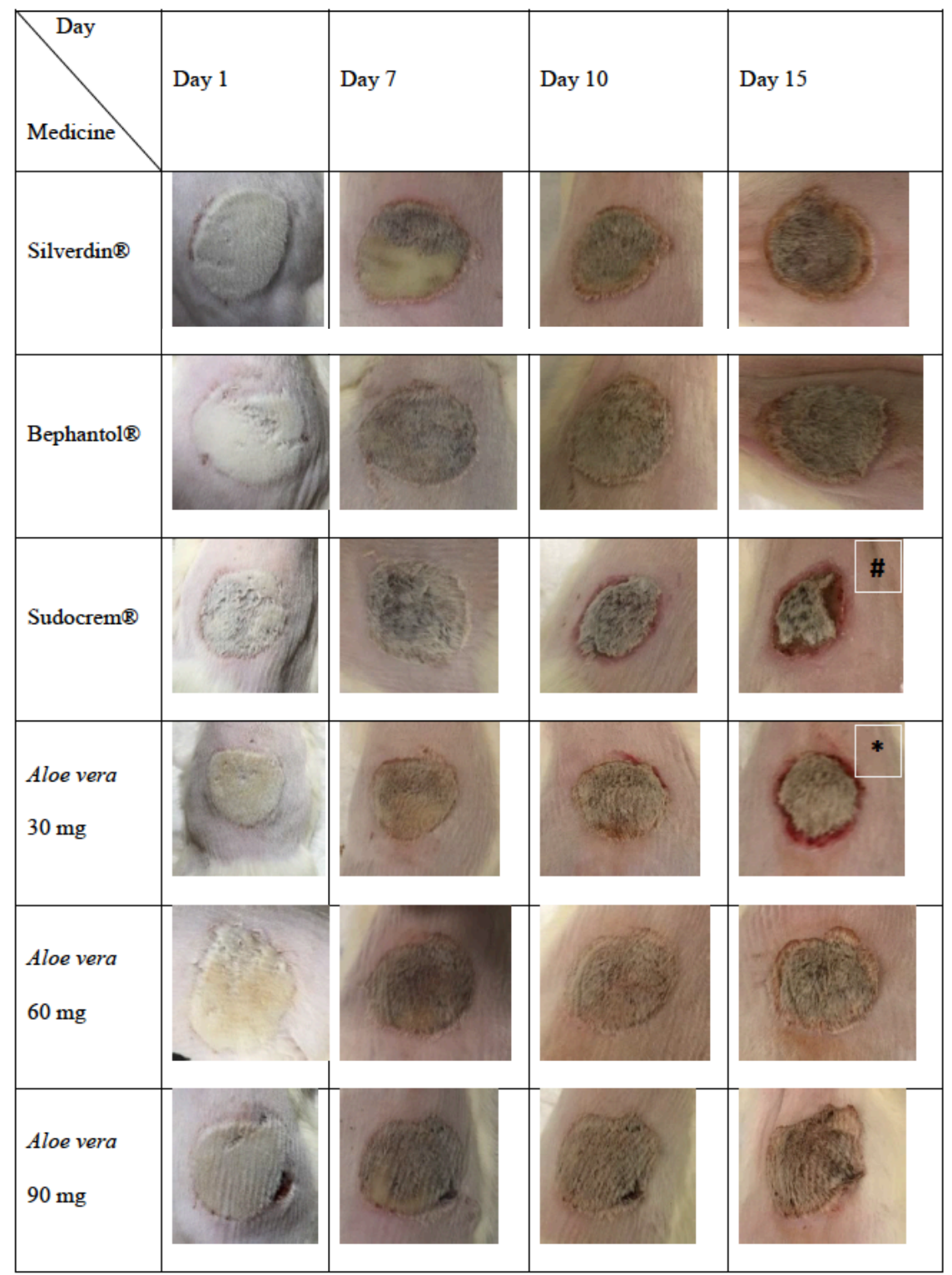

Figure 3. Burnt skin photos of experimental groups of that were taken on different days.

*: compared with other groups except Sudocream when $15^{\text {th }}$ days of treatment; \#: compared with all groups when $15^{\text {th }}$ days of treatment.

The result showed that the scar tissue was softer (not stiff or coarse) in the Sudocream and Aloe vera $30 \mathrm{mg}$ treated groups when compared with the others (Figure 3). Also, colour of wound secretion is more reddish in Aloe vera $30 \mathrm{mg}$ and Sudocream groups compared with other groups on the 15th day of the study (Figure 3). 


\section{DISCUSSION AND CONCLUSION}

Epidemiological studies around the world have shown that burns are one of the important reasons of death in community..$^{-11}$ The most observed type of burn is second-degree burn and in order to treat, various types of medicines are available. Aloe vera can also be used for healing burns. It has been reported to contain amino acids, tannins, lipids, steroids, enzymes, flavonoids, anthraquinones, phlorotannins, carbohydrates, alkaloids, terpenes, and saponins. ${ }^{12}$ These compounds in Aloe vera make it important in traditional and alternative medicine. The enhancing effect of Aloe vera to collagen levels providing strength and integrity to the tissue matrix and playing an important role in hemeostasis along with epithelialization were also previously reported..$^{13}$ Our findings showed that Aloe vera gel has a potential of healing the burn wounds on rats in line with the study by Farzadinia. ${ }^{14}$ On the other hand, contrary to expectations, not all doses of Aloe vera were found as the best drug. Among the Aloe vera gel drugs, the most effective dose was $30 \mathrm{mg}$, only. Aloe vera was better than silver sulfadiazine ${ }^{15}$ (Silverdin $\AA$ cream) but not than Sudocrem $\AA$ which contains zinc oxide. The other important parameter that shows wound healing is redness and thickness of periphery of burnt area. In accordance with the prior study performed by Emsen, our findings showed that wound periphery was more reddened and softer in groups which were treated with Aloe vera $30 \mathrm{mg}$ and Sudocremß. ${ }^{16}$ When comparing with other groups, Aloe vera wasn't the most effective drug among them but it was better than silver sulfadiazine which is the most used medicine in market. As a result of comparison, the most effective drug was Sudocrem and used for rashes in babies (burn area decreased to 2,307 $\mathrm{cm}^{2}$ from $7,069 \mathrm{~cm}^{2}$ ). According to our data, the biggest wound area was in the Silverdin $\AA$ group. Consequently, it can be said Aloe vera can be used in the treatment of second degree burns as an alternative medicine, instead of silver sulfadiazine. 


\section{REFERENCES}

1. American Burn Association/American College of Surgeons. Guidelines for the operation of burn centers. J. Burn Care Res. 2007, 28(1), 134-141.

2. Jeschke MG, Kamolz LP, Shahrokhi S. Burn Care and Treatment A Practical Guide. Yanık Bakımı ve Tedavisi, Translation into Turkish by: Erkılıç A, Ylldırım MS, Analay H. Nobel Tıp Kitabevleri Tic. Ltd. Şti. İstanbul, 2015.

3. Akyolcu N, Kanan N. Wound and Stoma Care, İstanbul Üniversitesi Florance Nightingale Hemşirelik Fakültesi 50. Yıl Yayınları, Nobel Tıp Kitabevleri Tic. Ltd. Şti. İstanbul, 2015 (in Turkish).

4. Kocatürk BK, Teyin M, Balcı Y, Eşiyok B. Evaluation of burn cases presenting in the Osmangazi University Hospital emergency room. Türkiye Klinikleri J. Med. Sci. 2oo5, 25(3), 400406.

5. Treatment Algorithm of Burn Injuries, Turkey Ministry of Health, 2012 (in Turkish).

6. Khorasani G, Hosseinimehr SJ, Azadbakht M, Zamani A, Mahdavi MR. Aloe Versus Silver Sulfadiazine Cream for Second-Degree Burns: A Randomized Controlled Study. Surg. Today 2009, 39(7), 587-591.

7. Rosca-Casian O, Parvu M, Vlase L, Tamas M. Antifungal Activity of Aloe Vera Leaves. Fitoterapia. $2007,78(3), 219-222$.

8. Lee D, Kim HS, Shin E, Do SG, Lee CK, Kim YM, Lee MB, Min KY, Koo J, Kim SJ, Nam ST, Kim HW, Park YH, Choi WS. Polysaccharide isolated from Aloe vera gel suppresses ovalbumin-induced food allergy through inhibition of Th2 immunity in mice. Biomed. Pharmacother. 2018, 101, 201-210.

9. Chalise PR, Shrestha S, Sherpa K, Nepal U, Bhattachan CL, Bhattacharya K. Epidemiological and bacteriological profile of burn patients at Nepal Medical College Teaching Hospital. Nepal Med. Coll. J. 2008, 10, 233-237.

10. Chen Y, Mo F, Yi QL, Jiang Y, Mao Y. Unintentional injury mortality and external causes in Canada from 2001 to 2007. Chronic Dis. Inj. Can. 2013, 33, 95-102.

11. Dale EL, Mueller MA, Wang L, Fogerty MD, Guy JS, Nthumba PM. Epidemiology of operative burns at Kijabe Hospital from 2006 to 2010: pilot study of a web-based tool for creation of the Kenya Burn Repository. Burns. 2013, 39, 788-795.

12. Ejoba R. Phytochemical constituents of some leaves extract of Aloe vera and Azadirachta indica plant species. Global Adv. Res. J. Environ. Sci. Toxicol. 2012, 1, 14-17.

13. Chithra P, Sajithlal GB, Chandrakasan G. Influence of aloe vera on the healing of dermal wounds in diabetic rats. J. Ethnopharmacol. 1998, 59, 195-201.

14. Farzadinia P, Jofreh N, Khatamsaz S, Movahed A, Akbarzadeh S, Mohammadi M, et al. Antiinflammatory and wound healing activities of Aloe vera, honey and milk ointment on second degree burns in rats. Int. J. Low Extrem. Wounds. 2016, 15, 241-247.

15. Akhoondinasab MR, Akhoondinasab M, Saberi M. Comparison of healing effect of aloe vera extract and silver sulfadiazine in burn injuries in experimental rat model. World J. Plast. Surg. 2014, 3(1), 29-34.

16. Emsen IM. A different and safe method of split thickness skin graft fixation: medical honey application. Burns. 2007, 33, 782-787. 